\title{
Entrepreneurial Education Development: Evidence from Russia
}

\author{
Yuri Pesotsky ${ }^{1}$, Olga Grigorieva ${ }^{1}$, Alexandra Chistova ${ }^{1}$ \\ ${ }^{1}$ Bauman Moscow State Technical University, ul. Baumanskaya 2-ya, 5/1, 105005, Moscow, Russia
}

\begin{abstract}
In Russia there is a problem of training professional entrepreneurs. Russian universities often train management specialists, that is, hired managerial staff and not entrepreneurs. The purpose of this study is to propose an integrated approach to training professional entrepreneurs in the higher education system of Russia. The study used questionnaire methods to identify the quality of entrepreneurial education at Russian universities, a competency-based approach to identify the main competencies of a professional entrepreneur, and comparative analysis in assessing the training system of entrepreneurs in other countries. As a result of the study, a conclusion was made about the chaotic development of entrepreneurial education in the system of higher education in Russia, a low assessment of this education by students; a system of indicators for assessing the competencies of a future entrepreneur was offered.
\end{abstract}

Keywords - entrepreneurs training, MBA, business education.

\section{Introduction}

For the economy of any country in the world, the development of entrepreneurship is a priority. In modern Russia, entrepreneurship is also one of the most important factors in a development of the economy.

DOI: 10.18421/TEM102-60

https://doi.org/10.18421/TEM102-60

Corresponding author: Yuri Pesotsky, Bauman Moscow State Technical University, Moscow, Russia

Email: pessotski@yandex.ru

Received: 14 Octobar 2020.

Revised: 25 April 2021.

Accepted: 05 May 2021.

Published: 27 May 2021.

(c) BY-NC-ND(C) 2021 Yuri Pesotsky, Olga Grigorieva \& Alexandra Chistova; published by UIKTEN. This work is licensed under the Creative Commons AttributionNonCommercial-NoDerivs 4.0 License.

The article is published with Open Access at www.temjournal.com
Over the past decades, Russia has seen an increase in the number of entrepreneurs, an increase in their level of professionalism, and an increase in the social responsibility of entrepreneurs. All these positive trends, however, have insufficient dynamics, largely due to the unsolved problem of forming a fullfledged system of entrepreneurial education in Russia. According to modern Russian scholars [14], [19], [20], the goals, content, forms of training and educational technologies used in teaching entrepreneurs at universities, in the framework of programs on various specialized fields, are characterized not only by diversity but also by unsystematic nature; only in isolated cases, they correspond to the best world standards.

The issues of development of business education are new not only for Russia; the problem of development and the future of business education is also of concern to foreign scholars [10], [12]. The basis of business education in the world is special MBA courses, the growth of demand for which is seen from year to year [7]. At the same time, competition between universities for students of MBA courses is intensifying [21]. Opportunities for obtaining online education for entrepreneurs are actively developing in the world, with up to $80 \%$ of participants in educational programs reporting the same effectiveness as traditional entrepreneurship courses [1], [16]. It should be noted that in the 2000s, undergraduate study programs for entrepreneurship of students were actively developing [22].

In the Russian Federation, the moment of formation of entrepreneurial education can be dated from the beginning of the 1990s, when with the beginning of market transformations in the Russian economy, the tasks of training personnel for the emerging business were sharply actualized, and the corresponding social educational order was formed. During this period, two features of Russian entrepreneurial education were established, to a certain extent retaining their significance up to the present [17]:

- non-critical use, as a theoretical, substantive and methodological basis for the training of entrepreneurs, of concepts, educational documents and materials developed in countries 
with established traditions of a market economy (USA, Germany, France, etc.);

- entrepreneurship training on the basis of exclusively short-term programs implemented in the context of non-formal education (courses for young entrepreneurs in accounting and taxation, business planning and investment; business training sessions and master classes), while each program is usually oriented toward the development of one aspect of entrepreneur's activities.

The indicated features significantly reduced the effectiveness of entrepreneurial education, which did not have signs of systematicity and integrity, continuity and succession.

Since the mid-1990s, an active discussion has unfolded in the scientific and educational community of Russia devoted to the problems of training and retraining of personnel in the field of entrepreneurship. During the discussion, it was concluded that it was necessary to develop and implement a set of measures aimed at training and retraining personnel ready to conduct business. In particular, an understanding has emerged of the need for state support of the emerging system of entrepreneurial education. This is reflected in the 2001 Concept for the Modernization of Russian Education for the Period until 2010, which notes the need to form in all graduates of universities, colleges and professional schools the readiness to start their own businesses [18].

Describing the situation prevailing in Russian entrepreneurial education in the early 2000s, the researchers noted the following shortcomings and problems to be resolved [17]:

- narrowly functional orientation of existing programs of education of entrepreneurs (marketing, management, financial activities, legal aspects), which does not provide an adequate relationship between the real professional activities of the entrepreneur and his/her professional education;

- the focus of existing secondary and higher vocational education programs on the training of professional executors (employees), while the tasks of forming graduates as businessmen are not implemented.

Thus, the social order for entrepreneurial education, adjusted by the beginning of the 2000 s, included two new components: first, the requirement for training professional entrepreneurs in the system of formal professional education (secondary and higher); second, the requirement for additional entrepreneurial education for specialists of secondary and higher qualifications in various areas. Note that neither requirement has been implemented so far, as modern researchers point out in recent publications [6], [13].

A significant step in the development of entrepreneurial education in Russia was taken in 2008, when leading Russian universities (including the Moscow State University, the St. Petersburg State University, the Higher School of Economics, the Moscow Financial and Industrial University "Synergy", the Moscow International Higher Business School MIRBIS) created the Russian Association for Entrepreneurship Education. The leading task of the Association was to determine the development of programmatic and educational materials for teaching entrepreneurship at the level of secondary vocational education, undergraduate, graduate and postgraduate programs, which are of a continuing nature. Thus, for the first time in Russia, a practical question was raised on the formation of an entrepreneurial education system based on the principles of continuity and continuity.

Thus, despite the attempts of some Russian universities to build a successive system of training professional entrepreneurs in Russia as a whole, the situation with business education is unsatisfactory.

In this regard, the purpose of this study is to propose an integrated approach to training professional entrepreneurs in the higher education system of Russia. To achieve this goal, the following tasks were put:

1) to analyze the current state of the system of higher education for training entrepreneurs, to evaluate feedback from students about the quality of training entrepreneurs at universities;

2) to propose a system of indicators for assessing the competencies of a future entrepreneur;

3) to propose the main approaches to the formation of a system of higher education of entrepreneurs in Russia.

\section{Materials and Methods}

The study used interrogation methods to identify the quality of entrepreneurial education in Russian universities, a competency-based approach to identify the main competencies of a professional entrepreneur, and comparative analysis in assessing the training system of entrepreneurs in other countries.

As part of the study, a survey of students from 32 Russian universities was conducted; more than 1,000 students took part in the study.

\section{Results}

The current stage in the development of entrepreneurial education in Russia can be characterized as the completion of primary formation 
and the establishment of a system [25]. The new stage in the development of Russian vocational education is characterized by fundamentally different tasks and requests, such as: scientific reflection of the results achieved, identification of the main problem areas and substantiation of priority areas of development; improving the quality of entrepreneurial education, developing its integration with the business sector, using its capabilities to increase the effectiveness of universities, etc. [17].

The following components can be distinguished in the current structure of domestic entrepreneurial education [19]:

1) Formal training: school, institutions of secondary vocational, higher (bachelor's, master's, postgraduate) and business education (MBA, DBA);

2) Corporate entrepreneurial training programs;

3) Training (advanced training) of entrepreneurs at regular sessions, courses, seminars, practical training sessions; this also includes relatively long training programs, including those with state funding, aimed at start-ups and participants in business incubators;

4) Informal education of children, youth, competent citizens in the form of business projects, business games;

5) Informal training tools in the form of various associations and exchange of experience.

Today, in Russia, entrepreneurial education programs include those in which students acquire entrepreneurial competencies, for example, programs called "Economics of Entrepreneurship", "Entrepreneurship in the Innovation Sphere", "Management of Small Businesses", "Organization of Entrepreneurship", "Innovation and Entrepreneurship (by Sectors)". Such programs are implemented at the undergraduate level at 58 universities, and at the master's level - at 32 universities, while most often there is only one entrepreneurial education program in the portfolio of universities (regardless of the level) [14]. Describing the profile of entrepreneurial programs, Klyuyev notes two features: firstly, most of them (regardless of the level of training) are concentrated in the field of economics and management; secondly, there is an almost complete absence of entrepreneurial learning paths in the natural-scientific, technical, humanitarian and other areas of training [14]. For comparison, in the United States in 1970, only 16 colleges and universities offered classes in entrepreneurship or small business; today, over 2300 colleges and universities offer these courses [24].

As part of the study, a survey of students from 32 Russian universities was conducted, and the following results were obtained:
1) There are no entrepreneurship courses at $60 \%$ of the universities surveyed; $17 \%$ introduced separate courses on entrepreneurship and/or innovative management; $23 \%$ of universities have specialized departments or business centers; at $8 \%$ of universities there is a strategy for the development of entrepreneurial education with a full cycle of support for startups;

2) About $60 \%$ of the students surveyed at Russian universities admitted that during their studies they did not have a single entrepreneurship course, while the remaining $40 \%$ were offered only one elective course;

3) Only $28.7 \%$ of the students surveyed at Russian universities "agree with the statement that conditions are created at their universities that encourage them to engage in entrepreneurial activity";

4) At all levels of professional education, there is still no initiative for the formation of entrepreneurial competencies; the vocational education system traditionally focuses on the "production" of future employees, and not on the self-employment or the ability of graduates to create their own businesses.

Thus, the development of entrepreneurial education in the system of higher education in Russia is somewhat insufficient. One of the reasons for this state of affairs is that most universities lack a clear understanding of what forms the competencies of an entrepreneur.

In the framework of global studies, abilities that are important for the formation of an entrepreneur is the ability to generate business ideas and not to be afraid to discuss them with the network/business community [4], [8], the ability to attract a team to implement a business project [2], [3], and also the ability to use the capabilities of the surrounding business infrastructure to implement a business [23].

In addition, there are some studies in which important competencies for an entrepreneur are a list from 12 [11] to 47 points, depending on the approach to analyzing the success of new enterprises: psychological, sociological and economic [5].

In the framework of this study, the authors' approach to building a graduate's competence model for the designed system of higher business education is proposed, which includes two main stages:

1) the formation of a set of professional competencies of an entrepreneur, ensuring that a graduate is ready for the implementation of the basic labor functions of the entrepreneur as an innovative businessman;

2) the formation of a set of general cultural competencies of an entrepreneur, the core of which is a set of managerial competencies. 
A special problem that has not yet been satisfactorily resolved either in the pedagogical science or in the university practice is an assessment of the level of formation of general cultural competencies; most often this problem is resolved formally or is completely ignored. Traditionally, the tasks of forming and evaluating general cultural competencies are distributed among all disciplines of the educational program. In this situation, the general cultural competencies of a future entrepreneur are formed and evaluated "by a leftover principle"; the responsibility for their formation distributed among teachers of various disciplines leads to the fact that the status of general cultural competencies in the educational program of a university turns out insignificant.

However, the specifics of the entrepreneur's professional activity are such that the core of his/her general cultural competencies can be brought closer to the importance of the entrepreneur's professional competencies. While the general cultural competencies of an entrepreneur, in general, can be correlated with the professional competencies of a manager, the core of the general cultural competencies of an entrepreneur is the part of managerial competencies that ensures readiness for project management. Therefore:

- the formation of professional and general competencies of a university graduate who has mastered the entrepreneurial training program cannot be established in isolation from each other;

- assessment of the formation of general cultural competencies of an entrepreneur can and should be carried out as an assessment of his/her readiness for the implementation of the professional functions of a manager, first of all, readiness for project management;

- when assessing the level of effectiveness of a competence-based educational process, it is necessary to take into account not only the degree of formation of knowledge and skills of graduates but also the presence of meaningful experience in their activities, as well as their motivational and psychological readiness for relevant activities.

Based on the above provisions, a system has been designed for assessing the effectiveness of the entrepreneurial training of students. As a first step, a set of criteria has been identified that integrally characterizes the effectiveness of training an entrepreneur in a university, namely:

1) The value-semantic criterion characterizes the degree of formation and awareness of the value foundations of the entrepreneurial activity of a personality;

2) The motivational-psychological criterion characterizes the entrepreneurial orientation of a personality and its psychological readiness for entrepreneurial activity;

3) The professional competence criterion characterizes the degree of formation of the set of professional competencies (Hard Skills) necessary for the successful start of entrepreneurial activity;

4) The general cultural competence criterion characterizes the degree of formation of the set of general cultural competencies (Soft Skills) necessary for the successful start of entrepreneurial activity.

At the next stage, each of the selected criteria was specified based on one or more indicators. Further, on the basis of the criteria-level approach, for each of the indicators three qualitatively different levels of manifestation (high, medium, low) were identified, characterized by certain level descriptors (see Table 1). The possibility of mathematical processing of the obtained results is ensured by assigning a certain quantitative value (expert score) to each level: low level - 0 points, medium level -1 point, high level 2 points. 
Table 1. Criteria and performance indicators for the formation of general cultural competencies of an entrepreneur in the higher education system

\begin{tabular}{|c|c|c|c|}
\hline \multirow{2}{*}{ Indicators } & \multicolumn{3}{|c|}{ Levels and level descriptors } \\
\hline & High (2) & Medium (1) & Low (0) \\
\hline \multicolumn{4}{|c|}{ 1. VALUE-SEMANTIC CRITERION } \\
\hline $\begin{array}{l}\text { 1.1. Balance of } \\
\text { entrepreneurial } \\
\text { values }\end{array}$ & $\begin{array}{l}\text { Awareness of the high } \\
\text { importance of the core values of } \\
\text { entrepreneurial activity in their } \\
\text { natural hierarchy (creation- } \\
\text { development-freedom-profit), } \\
\text { understanding of the social } \\
\text { mission of entrepreneurship }\end{array}$ & $\begin{array}{l}\text { Understanding of the social } \\
\text { mission of entrepreneurship } \\
\text { and the core values of } \\
\text { entrepreneurial activity, } \\
\text { coupled with a certain one- } \\
\text { sidedness in their personal } \\
\text { acceptance }\end{array}$ & $\begin{array}{l}\text { A tendency toward an } \\
\text { egocentric perception of the } \\
\text { values of entrepreneurial } \\
\text { activities (exclusive orientation } \\
\text { to profit), lack of awareness of } \\
\text { the social mission of } \\
\text { entrepreneurship }\end{array}$ \\
\hline \multicolumn{4}{|c|}{ 2. MOTIVATIONAL-PSYCHOLOGICAL CRITERION } \\
\hline $\begin{array}{l}\text { 2.1. Entrepreneuri } \\
\text { al intentions }\end{array}$ & $\begin{array}{l}\text { Strong intentions to create one's } \\
\text { own business/join the founders } \\
\text { of the existing business in the } \\
\text { near future }\end{array}$ & $\begin{array}{l}\text { Strong intentions to create } \\
\text { one's own business/join the } \\
\text { founders of the existing } \\
\text { business in the long term }\end{array}$ & $\begin{array}{l}\text { No intention to create one's } \\
\text { own business/join the founders } \\
\text { and/or serious doubts about this } \\
\text { possibility }\end{array}$ \\
\hline $\begin{array}{l}\text { 2.2. Confidence in } \\
\text { future }\end{array}$ & $\begin{array}{l}\text { High confidence in one's own } \\
\text { future due to the opportunity to } \\
\text { create one's own business }\end{array}$ & $\begin{array}{l}\text { High confidence in one's own } \\
\text { future, not related to the } \\
\text { possibility of creating one's } \\
\text { own business }\end{array}$ & $\begin{array}{l}\text { Uncertainty in one's own } \\
\text { future, doubts about one's own } \\
\text { ability to successfully build } \\
\text { their lives }\end{array}$ \\
\hline \multicolumn{4}{|c|}{ 3. PROFESSIONAL COMPETENCE CRITERION } \\
\hline 3.1. Awareness & $\begin{array}{l}\text { Complete, adequate and holistic } \\
\text { knowledge of business and } \\
\text { modern entrepreneurial activity }\end{array}$ & $\begin{array}{l}\text { Generally adequate, but not } \\
\text { quite systemic knowledge of } \\
\text { business and entrepreneurial } \\
\text { activity }\end{array}$ & $\begin{array}{l}\text { Disparate and/or one-sided } \\
\text { ideas about business and } \\
\text { entrepreneurial activity }\end{array}$ \\
\hline $\begin{array}{l}\text { 3.2. Formation of } \\
\text { skills }\end{array}$ & $\begin{array}{l}\text { Successful and meaningful } \\
\text { experience in using in the } \\
\text { educational environment and } \\
\text { outside it the problem- } \\
\text { searching, evaluative-analytical, } \\
\text { planning and design and other } \\
\text { skills that provide professional } \\
\text { competence of an entrepreneur }\end{array}$ & $\begin{array}{l}\text { Successful and meaningful } \\
\text { experience in using in the } \\
\text { educational system of the } \\
\text { university of the main } \\
\text { problem-searching, } \\
\text { evaluative-analytical, } \\
\text { planning and design and other } \\
\text { skills stipulated by the } \\
\text { educational program of } \\
\text { entrepreneurial training }\end{array}$ & $\begin{array}{l}\text { Partially successful, but not } \\
\text { always meaningful use of the } \\
\text { main problem-searching, } \\
\text { evaluative-analytical, planning } \\
\text { and design and other skills } \\
\text { stipulated by the educational } \\
\text { program of entrepreneurial } \\
\text { training }\end{array}$ \\
\hline 3.3. Productivity & $\begin{array}{l}\text { Having one's own business } \\
\text { project that has proven its } \\
\text { viability in practice (entering a } \\
\text { startup in the market) }\end{array}$ & $\begin{array}{l}\text { Having one's own business } \\
\text { project that has successfully } \\
\text { passed a public presentation } \\
\text { (a startup fully prepared for } \\
\text { implementation) }\end{array}$ & $\begin{array}{l}\text { No own business project } \\
\text { (startup) that has passed a } \\
\text { public presentation and was } \\
\text { prepared for implementation }\end{array}$ \\
\hline \multicolumn{4}{|c|}{ 4. GENERAL COMPETENCE CRITERION } \\
\hline $\begin{array}{l}\text { 4.1. Self- } \\
\text { determination and } \\
\text { responsibility }\end{array}$ & 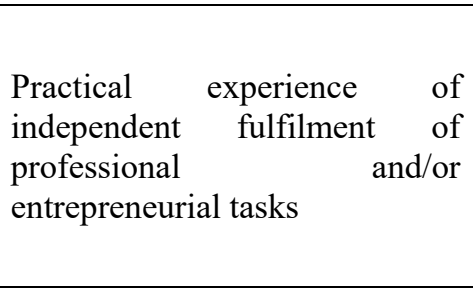 & $\begin{array}{l}\text { Readiness demonstrated } \\
\text { during the training sessions to } \\
\text { take responsibility for the } \\
\text { consequences of one's own } \\
\text { actions, ability to make } \\
\text { decisions independently, } \\
\text { including in critical situations }\end{array}$ & $\begin{array}{l}\text { Need to seek external help in } \\
\text { solving new and non-standard } \\
\text { tasks and/or a tendency to } \\
\text { evade and shift responsibility }\end{array}$ \\
\hline 4.2. Creativity & $\begin{array}{l}\text { Presence of at least one own } \\
\text { business idea that has } \\
\text { successfully passed the stage of } \\
\text { commercialization; stable } \\
\text { creative activity and initiative }\end{array}$ & $\begin{array}{l}\text { A large number of promising } \\
\text { business ideas that have } \\
\text { successfully passed the stage } \\
\text { of public presentation; } \\
\text { noticeable creative activity } \\
\text { and initiative }\end{array}$ & $\begin{array}{l}\text { A tendency to reproduce } \\
\text { standard schemes, a tendency } \\
\text { to act according to a pattern, a } \\
\text { lack of need to take initiative } \\
\text { and go beyond the framework } \\
\text { of proven approaches }\end{array}$ \\
\hline $\begin{array}{l}\text { 4.3. Communicati } \\
\text { ons and } \\
\text { interaction }\end{array}$ & $\begin{array}{l}\text { Presence of practical experience } \\
\text { (gained and meaningful in one's } \\
\text { own entrepreneurial and/or } \\
\text { professional activities), } \\
\text { successful } \\
\begin{array}{l}\text { communication, conflict-free } \\
\text { communication, constructive }\end{array}\end{array}$ & $\begin{array}{l}\text { Readiness demonstrated } \\
\text { during the training sessions to } \\
\text { successfully carry out } \\
\text { business communication and } \\
\text { constructively interact with } \\
\text { various entities in solving } \\
\text { entrepreneurial problems, }\end{array}$ & $\begin{array}{l}\text { Presence of certain problems in } \\
\text { communication (illiterate } \\
\text { construction of speech, a lack } \\
\text { of culture and ethics, or the } \\
\text { like) }\end{array}$ \\
\hline
\end{tabular}




\begin{tabular}{|c|c|c|c|}
\hline & $\begin{array}{l}\text { interaction with partners and } \\
\text { customers }\end{array}$ & $\begin{array}{l}\text { coordinating interests and } \\
\text { resolving emerging problems }\end{array}$ & \\
\hline $\begin{array}{l}\text { 4.4. Project } \\
\text { management }\end{array}$ & $\begin{array}{l}\text { Successful (documented) } \\
\text { experience in developing a } \\
\text { business project, forming a } \\
\text { project team, launching a } \\
\text { project, and practice of } \\
\text { managing it }\end{array}$ & $\begin{array}{l}\text { Readiness demonstrated } \\
\text { during the training sessions } \\
\text { and practice to design and } \\
\text { present a project concept, } \\
\text { manage the life cycle, quality, } \\
\text { project cost, show leadership, } \\
\text { and form a project team }\end{array}$ & $\begin{array}{l}\text { Incomplete or insufficient } \\
\text { formation of a set of } \\
\text { competencies, abilities, and } \\
\text { skills that ensure readiness for } \\
\text { project management }\end{array}$ \\
\hline
\end{tabular}

Source: developed by the author

The practical use of the system of criteria, indicators and level descriptors presented in Table 1 requires the following provisions.

1. The objects being evaluated are the phenomena, the manifestation of which is difficult to track, verify and clearly demonstrate. In this regard, to collect evidence of the status of indicators, "soft" assessment methods (expert assessment and self-assessment) should be used. At the same time, to achieve maximum objectivity, a criteria-based assessment of the degree of formation of a given set of professional and general cultural competencies of graduates was supplemented by using data on the results of graduates passing the state final attestation, the assessment of which is an additional evidence of the level of formation of professional competencies.

2. As a central indicator of motivational and personal training, the authors consider the entrepreneurial intentions of graduates. According to Krueger, Reilly and Carsrud [15], entrepreneurial intentions are a key prerequisite for actual entrepreneurial actions and creating one's own business. Following Eyel and Durmaz [9], the authors consider them "as a reflection of the degree of motivation and readiness to make efforts to implement actual behavior" in terms of starting one's own business.

3. The criteria and indicators presented in Table 1 can be used to assess the effectiveness of entrepreneurial education not only individually but also in comparison with each other, to identify the degree of balance of the entrepreneurial training results. A higher level of balanced entrepreneurial training indicates a decrease in the internal inconsistency of the entrepreneur's personality development, an increase in the degree of mutual balance of his/her professionally significant qualities.

To solve this problem, the authors introduced four additional indicators characterizing the balance of entrepreneurs training results:

- $\mathrm{B} 1_{\mathrm{PC}}$ - the balance between external assessment and student self-assessment of the level of development of his/her professional entrepreneurial competencies;

- $\mathrm{B} 1_{\mathrm{GC}}$ - the balance between external assessment and student self-assessment of the level of development of his/her general cultural entrepreneurial competencies;

- B2 - the balance between the levels of acquired professional and general entrepreneurial competencies in a student;

- B3 - the balance between the level of entrepreneurial intentions of a student and the level of formation of his/her professional and general cultural entrepreneurial competencies.

To obtain objective data, a special mathematical apparatus was developed that allows one to calculate the values of each of the above indicators for the experimental and control groups.

The value of the balance indicator between the external assessment and the student's self-assessment of the level of development of his/her entrepreneurial competencies (professional or general) is calculated by the formula:

$$
\mathrm{B} 1=\left(\sum_{i=1}^{n}|A i-S A i|\right) / n
$$

where:

$A_{i}-$ external assessment of the level of development of competencies of the $i$-th student, calculated as the arithmetic average of the level of manifestation of each of the indicators that make up the professional competence criterion for $\mathrm{B} 1_{\mathrm{PC}}$, or general cultural competence criterion for $\mathrm{B} 1_{\mathrm{GC}}$;

$\mathrm{SA}_{\mathrm{i}}$ - self-assessment of the level of development of competencies of the $i$-th student, calculated as the arithmetic average of the level of manifestation of each of the indicators that make up the professional competence criterion for $\mathrm{B} 1_{\mathrm{PC}}$, or general cultural competence criterion for $\mathrm{B} 1_{\mathrm{GC}}$;

$\mathrm{n}$ - the number of students in this sample.

The value of the indicator of the balance between the levels of formation of professional and general competencies of an entrepreneur in a student is calculated by the formula:

$$
\mathrm{B} 2=\left(\sum_{i=1}^{n}|P C i-S A C i|\right) / n
$$

where:

$\mathrm{PC}_{\mathrm{i}}$ - external assessment of the level of development of professional competencies of the $i$-th student, calculated as the arithmetic average of the level of manifestation of each of the three indicators of the professional competence criterion; 
$\mathrm{SA}_{\mathrm{i}}$ - self-assessment of the level of development of competencies of the $i$-th student, calculated as the arithmetic average of the level of manifestation of each of the four indicators of the general cultural competence criterion;

$\mathrm{n}$ - the number of students in this sample.

The value of the indicator of the balance between the level of entrepreneurial intentions of the student and the level of formation of his/her professional and general cultural entrepreneurial competencies is calculated by the formula:

$$
\mathrm{B} 3=\left(\sum_{i=1}^{n}|E I i-(P C i+S A C i)| / 2\right) / n
$$

where:

$\mathrm{EI}_{\mathrm{i}}$ - self-assessment by the $i$-th student of the level of formation of his/her entrepreneurial intentions;

$\mathrm{PC}_{\mathrm{i}}$ - external assessment of the level of development of professional competencies of the $i$-th student, calculated as the arithmetic average of the level of manifestation of each of the three indicators of the professional competence criterion;

$\mathrm{SA}_{i}$ - self-assessment of the level of development of competencies of the $i$-th student, calculated as the arithmetic average of the level of manifestation of each of the four indicators of the general cultural competence criterion;

$\mathrm{n}$ - number of students in this sample.

The value of each of the indicators of balance $\left(\mathrm{B} 1_{\mathrm{PC}}, \mathrm{B} 1_{\mathrm{GC}}, \mathrm{B} 2, \mathrm{~B} 3\right)$ can range from 0 to 2 , which allows one to highlight different levels of balance, indicating a different degree of achievement of the set results of entrepreneurial training:

- $\left[\begin{array}{lll}0 & \ldots & 0.25\end{array}\right]$ - high balance (no more than onequarter of the students in this sample have a discrepancy in the values of the comparable indicators of no more than 1 point);

- $\left[\begin{array}{lll}0.25 & \ldots & 0.5\end{array}\right]$ - average balance;

- $[0.5 \ldots 1.0]$ - low balance;

- $\left[\begin{array}{lll}1.0 & \ldots & 2.0\end{array}\right]$ - very low balance, which with a high degree of probability, indicates the inaccuracy of the data.

\section{Conclusion}

In conclusion, summarizing the main features of the modern stage of development of entrepreneurial education at Russian universities:

1) The task of building a system of higher entrepreneurial education is recognized as a significant task at the level of the state and the academic and educational community;

2) All available models of entrepreneurial education at universities, despite their apparent diversity, are focused on preparing a graduate for the role of an entrepreneur as an additional, secondary goal of education and are implemented within other (non-entrepreneurial) areas of training;

3) A complex of conditions necessary for the effective formation of a set of entrepreneurial competencies in graduates is created only at few universities of the country that implement the model of "entrepreneurial university"; at most universities, individual entrepreneurial courses are implemented on the basis of traditional forms and teaching methods using unprepared staff;

4) The task of forming the entrepreneur's professional competencies related to his/her financial and economic training is mainly solved, while the tasks of forming general competencies most often remain outside the scope of entrepreneurial education at Russian universities.

In these conditions, the search for a system-forming principle, ensuring the integrity and effectiveness of training students for their own entrepreneurial activities in small and medium-sized businesses, in the existing conditions of non-core (for entrepreneurs) higher education, becomes an urgent task. An adequate solution to this problem will make it possible to take a breakthrough step on the path to the development of higher entrepreneurial education in modern Russia. 


\section{References}

[1]. Allen, I. E., \& Seaman, J. (2005). Growing by degrees: Online education in the United States, 2005. Sloan Consortium (NJ1).

[2]. Alvarez, S. A., \& Busenitz, L. W. (2001). The entrepreneurship of resource-based theory. Journal of management, 27(6), 755-775.

https://doi.org/10.1177/014920630102700609

[3]. Barney, J. (1991). Firm resources and sustained competitive advantage. Journal of management, 17(1), 99-120.

[4]. Baručić, A., \& Umihanić, B. (2016). Entrepreneurship education as a factor of entrepreneurial opportunity recognition for starting a new business. Management: Journal of Contemporary Management Issues, 21(2), 27-44.

[5]. Brown, T. C., \& Hanlon, D. (2016). Behavioral criteria for grounding entrepreneurship education and training programs: A validation study. Journal of Small Business Management, 54(2), 399-419. https://doi.org/10.1111/jsbm.12141

[6]. da Cruz, M. D. F. P., Ferreira, J. J., \& Kraus, S. (2021). Entrepreneurial orientation at higher education institutions: State-of-the-art and future directions. The International Journal of Management Education, 19(2), 100502.

https://doi.org/10.1016/j.ijme.2021.100502

[7]. Doti, J.L. and Tuggle, F.D. (2005). Doing the Math on MBA Enrollment. BizEd, 4(5), 46-50.

[8]. Eid, R., Badawi, A., Selim, H., Elgohary, H. (2017). Entrepreneurship Education and Employability of UAE Higher Education Business Students. Proceeding of The 10th International Conference of Education, Research And Innovation (ICERI 2017), 7410-7419.

[9]. Eyel, C. Ş., \& Durmaz, İ. B. V. (2019). Entrepreneurial Intentions of Generation-Z: Compare of Social Sciences and Natural Sciences Undergraduate Students at Bahçeşehir University. Procedia Computer Science, 158, 861868. https://doi.org/10.1016/j.procs.2019.09.124

[10]. Friga, P. N., Bettis, R. A., \& Sullivan, R. S. (2003). Changes in graduate management education and new business school strategies for the $21 \mathrm{st}$ century. Academy of Management Learning \& Education, 2(3), 233-249.

[11]. Giannantonio, C. M., \& Hurley-Hanson, A. E. (2016). Entrepreneurial Characteristics and Careers: American High-Tech Entrepreneurs. Journal of Business \& Management, 22(2).

[12]. Hawawini, G. (2005). The Future of Business Schools. the Journal of Management Development, 24(9), 770-782.

https://doi.org/10.1108/02621710510621286
[13]. Klyuyev, A.K. and Yashin, A.A. (2016). Programmy predprinimatel'skogo obrazovaniya $\mathrm{v}$ sovremennom universitete. Vysshee obrazovanie, (1), 22-33.

Retrieved from:

https://cyberleninka.ru/article/n/programmypredprinimatelskogo-obrazovaniya-v-sovremennomuniversitete (in Russian). [accessed: 10 July 2020].

[14]. Klyuyev, A.K., Bagirova, A.P., Yashin, A.A. and Zabokritskaya, L.D. (2017). Predprinimatel'skoe obrazovanie v universitetah strany: masshtaby, vidy programm, balans kompetencij. Sovremennaya konkurenciya, 61 (11), 6-20. Retrieved from: https://cyberleninka.ru/article/n/predprinimatelskoeobrazovanie-v-universitetah-strany-masshtaby-vidyprogramm-balans-kompetentsiy (in Russian). [accessed: 10 September 2020].

[15]. Krueger Jr, N. F., Reilly, M. D., \& Carsrud, A. L. (2000). Competing models of entrepreneurial intentions. Journal of business venturing, 15(5-6), 411-432.

https://doi.org/10.1016/S0883-9026(98)00033-0

[16]. Kumar, P., Kumar, A., Palvia, S., \& Verma, S. (2019). Online business education research: Systematic analysis and a conceptual model. The International Journal of Management Education, 17(1), 26-35. https://doi.org/10.1016/j.ijme.2018.11.002

[17]. Larisa, L., Ildar, T., \& Elena, R. (2015). Business education market in Russia: current state and development outlook. Procedia-Social and Behavioral Sciences, 191, 391-395. https://doi.org/10.1016/j.sbspro.2015.04.390

[18]. Ministry of Education of the Russian Federation (2002). O Koncepcii modernizacii rossijskogo obrazovaniya na period do 2010 goda, approved by Order No. 393 of the Ministry of Education of the Russian Federation dated 11 February 2002, Retrieved from: http://docs.cntd.ru/document/901816019 [accessed: 10 October 2020] (in Russian).

[19]. Vysshee predprinimatel'skoe, R. Y. B. (2015). obrazovanie v Rossii: diagnostika problemy. Vysshee obrazovanie v Rossii, (11), 5-17. Retrieved from: https://cyberleninka.ru/article/n/vyssheepredprinimatelskoe-obrazovanie-v-rossiidiagnostika-problemy (in Russian). [accessed: 05 October 2020].

[20]. Rubin, Y.B., Alekseeva, E.V., Lednev, M.V. and Mozhukhin, D.P. (2017). Obuchenie predprinimatel'stvu: puti ukoreneniya v vuzovskom segmente rossijskogo obrazovaniya. Sovremennaya konkurenciya, 61 (11), 30-56. Retrieved from: https://cyberleninka.ru/article/n/obucheniepredprinimatelstvu-puti-ukoreneniya-v-vuzovskomsegmente-rossiyskogo-obrazovaniya (in Russian). [accessed: 10 September 2020]. 
[21]. Schworm, S. K., Cadin, L., Carbone, V., Festing, M., Leon, E., \& Muratbekova-Touron, M. (2017). The impact of international business education on career success-Evidence from Europe. European Management Journal, 35(4), 493-504. https://doi.org/10.1016/j.emj.2017.02.009

[22]. Stăiculescu, C., Richiţeanu-Năstase, E. R., \& Dobrea, R. C. (2015). The university and the business environment-Partnership for education. ProcediaSocial and Behavioral Sciences, 180, 211-218. https://doi.org/10.1016/j.sbspro.2015.02.107
[23]. Thompson, A. A., Peteraf, M. A., Gamble, J. E., \& Strickland, A. J. (2018). Crafting and executing strategy: The quest for competitive advantage: Concepts and cases (21st ed.). New York, NY: McGraw Hill Education.

[24]. Torrance, W. (2013). Entrepreneurship Education Comes of Age on Campus. Kansas City, USA: Ewing Marion Kauffman Foundation.

[25]. Alexander, U., \& Evgeniy, P. (2012). The entrepreneurial university in Russia: from idea to reality. Procedia-Social and Behavioral Sciences, 52, 45-51. https://doi.org/10.1016/j.sbspro.2012.09.440 